\title{
Kalanchoe crop development under different levels of irrigation
}

\author{
Fátima Cibele Soares ${ }^{1 *}$, Ana Rita Costenaro Parizi ${ }^{2}$, Francieli Ribeiro Corrêa ${ }^{1}$, \\ Francielle Altíssimo Bortolás ${ }^{1}$, Jumar Luis Russi ${ }^{1}$ \\ 10.1590/0034-737X201663050007
}

\begin{abstract}
Despite its importance in the floriculture sector, irrigation management of kalanchoe is characterized by empiricism, being necessary further studies on the use of water by this crop. Thus, the objective of this study is to analyze the several effects of irrigation levels on the growth of kalanchoe crop conducted in greenhouse in the municipality of Alegrete, state of Rio Grande do Sul. The experiment was conducted in a 7 x $15 \mathrm{~m}$ protected environment. The experimental design was completely randomized, with four treatments (irrigation levels corresponding to 40,60, 80 and 100\% of the pot water retention capacity - PC) and four repetitions, totaling sixteen plots. The crop cycle was 224 days after transplanting and the applied average depths were: $451.82 ; 367.38 ; 282.94 ; 198.51 \mathrm{~mm}$ for treatments: $100 ; 80 ; 60$ and $40 \%$ of PC, respectively. Canopy area and number of leaves per plant were evaluated over the crop cycle. In the end of the cycle, the canopy diameter, number of inflorescences per plant and the number of flowers per plant were evaluated. No significant differences were found only to the canopy area, by the F test. Irrigation water depths between 40 and $70 \%$ of the pot capacity were more appropriate for the crop growth in the study region. The cultivar presented the best development at irrigation levels below the maximum vessel water retention capacity, that is, it is resistant to drought.
\end{abstract}

Key words: floriculture; greenhouse; irrigation management; kalanchoe blossfeldiana Poelln.

\section{RESUMO}

\section{Desenvolvimento da cultura do kalanchoe submetida a diferentes níveis de irrigação}

Apesar de sua importância no setor da floricultura, o manejo da irrigação em kalanchoe é caracterizado pelo empirismo, necessitando-se de maiores estudos quanto ao uso de água pela cultura. Dentro deste contexto, o objetivo deste trabalho é analisar os efeitos de diversos níveis de irrigação sobre o desenvolvimento da cultura do kalanchoe, conduzida em estufa plástica no município de Alegrete, RS. O experimento foi conduzido em ambiente protegido de 7 x $15 \mathrm{~m}$. O delineamento experimental foi inteiramente aleatorizado, com quatro tratamentos (níveis de irrigação correspondentes a 40, 60, 80 e 100\% da capacidade de retenção de água do vaso - CV), e quatro repetições, totalizando dezesseis parcelas. O ciclo da cultura foi de 224 dias após transplante e as lâminas médias aplicadas foram: 451,82; 367,38; 282,94; 198,51 mm, para os tratamentos de 100; 80; 60 e 40\% da CV, respectivamente. Ao longo do ciclo da cultura foram avaliadas a área do dossel e número de folhas por planta. No final do ciclo avaliou-se o diâmetro da copada, número de inflorescências por planta e número de flores por planta. Somente não houve diferença significativa para a área do dossel, pelo teste F. Lâminas de irrigação entre 40 e $70 \%$ da capacidade de vaso mostraram-se mais adequadas para a condução da cultura, na região do estudo. A cultivar apresentou o melhor desenvolvimento quando submetida a níveis de irrigação inferiores à máxima capacidade de retenção de água do vaso, ou seja, a mesma apresenta resistência ao déficit hídrico.

Palavras-chave: kalanchoe blossfeldiana Poelln; manejo da irrigação; ambiente protegido; floricultura.

\footnotetext{
Submitted on December $17^{\text {th }}, 2014$ and accepted on May $24^{\text {th }}, 2016$.

${ }^{1}$ Universidade Federal do Pampa, Alegrete, Rio Grande do Sul, Brazil. fatimacibele1@gmail.com; fraan_vl_@hotmail.com; fran.bortolaz@hotmail.com; jrussi@gmail.com

${ }^{2}$ Instituto Federal Farroupilha, Alegrete, Rio Grande do Sul, Brazil. ana.parizi@iffarroupilha.edu.br

*Corresponding author: fatimacibele1@gmail.com
} 


\section{INTRODUCTION}

The trade of flowers and ornamental plants in Brazil is growing. According to the latest survey by the Instituto Brasileiro de Floricultura (Brazilian Institute of Floriculture) Ibraflor, in 2014, the sector generated $\mathrm{R} \$ 5.7$ billion, and for 2015 , a growth in the order of $8 \%$ over the previous year is expected (Ibraflor, 2015). Brazil has three thousand varieties of flowers and ornamental plants. Concerning the trade, roses are the most sold, followed by chrysanthemum (Donatto, 2014).

According to data presented by Ibraflor, the sector of flowers and ornamental plants responds for the creation of more than 206,000 direct jobs, of which 102,000 (49.5\%) are allocated directly in production activities; 6.4 thousand (3.1\%) in the distribution and logistics of distribution; $82,000(39.7 \%)$ in the retail and $15,600(7.7 \%)$ in functions such as support, managements and others (Ibraflor, 2015).

However, the success of this sector is related to some key factors such as: management of production systems; use of technologies in the systematization of irrigation; and quality of labor. Management is the main classifier of the final product, and the cultivation of ornamental plants in greenhouses is recommended due to weather adversities (Ibraflor, 2015).

Among the several species of flowers grown in pots for commercial purposes and greatly accepted in the market is Kalanchoe blossfeldiana Poelln (Agronline, 2008 Ibraflor, 2015). This crop, when grown in pots, needs large amounts of water and fertilizers (Parizi et al., 2010).

Bellé (2000) highlights that in ornamental potted plants, among the most important tasks for the production is irrigation, in particular in crops in greenhouses where the plants do not receive rainwater and the water is supplied exclusively through irrigations.

According to Kämpf (2000), the amount of water available in the substrate is one of the most important factors for the crop because it is related to vegetative growth and crop productivity, especially in protected environment. Periods of water déficit and excess causes slow development, low productivity, occurrence of diseases, etc., inhibiting the crop growth.

To set the required water depth and the correct timing of water applications is a critical parameter for proper irrigation management. By knowing the amount of water to be supplied to the plants, it is possible to ensure a more efficient irrigation management, reducing costs, avoiding water excesses and improving the quality of production (Vieira et al., 2000; Matiello et al., 2005).

With the current policies of water resources, studies on irrigated agriculture are focused mainly on maximizing water use efficiency. The irrigation methods and equipment can and should be improved to reduce losses and induce an adequate management together with the soil, plant and climate, resulting in efficiency gains (Paz et al., 2000). Thus, control measurements of the amount of water applied by using techniques that improve the efficiency of application of water through irrigation are essential to reduce the impacts on water resources.

The region of the western border of the Rio Grande do Sul state is characterized by being a typical producing region of irrigated rice and livestock. However, there are small farms, which are unsuitable for these activities and that could exploit other crops. An ideal agriculture activity for family farms that provides income for small farmers, due to the high profitability obtained in small cropped areas, is the production of flowers and ornamental plants (Epamig, 2015).

In addition, floriculture is also an agricultural activity that is characterized by intensive cultivation, by the great demand for labor per cropped area, generating jobs and income for the producing region (Sebrae, 2010). However, many aspects related to floriculture are still unknown and requires further studies to generate technologies that provide the strengthening of the agricultural sector in the state.

Due to the importance that floriculture currently represents in the Brazilian agribusiness, the need to introduce alternative sources of income and employment for small farmers in the western border region of the Rio Grande do Sul state and the need to maximize water use efficiency in agriculture, this study was carried out with the objective of analyzing the effects of irrigation levels on the development of kalanchoe crop, conducted in greenhouse in the region of Alegrete, state of Rio Grande do Sul.

\section{MATERIAL AND METHODS}

The experiment was carried out in the municipality of Alegrete, state of Rio Grande do Sul, whose reference geographic coordinates are $29^{\circ} 42^{\prime} 32.7^{\prime \prime} \mathrm{S}$ and 55³1'31.7" W. According to the Köppen classification, the climate is classified as $\mathrm{Cfa}$, that is, humid subtropical without dry season and temperatures ranging from $14.3^{\circ} \mathrm{C}$ in winter to $26.3{ }^{\circ} \mathrm{C}$ in summer, with an average annual rainfall of 1,400 mm (Kuinchtner \& Buriol, 2001). However, due to seasonal variability of rainfall in the western border region of the State of Rio Grande do Sul, there are periods of droughts that cause significant losses in grain production (Ben, 2015).

The experiment was set in a protected environment with $7 \mathrm{~m}$ in width, $15 \mathrm{~m}$ in length and $3 \mathrm{~m}$ in height. The structure is made of galvanized steel, open in the sides and cover with low density transparent polyethylene.

The variety of kalanchoe (Kalanchoe blossfeldiana Poelln) used was "Simone". Plants were grown in plastic 
pots of $11 \mathrm{~cm}$ of height and volume of about $1251 \mathrm{~cm}^{3}$. They were filled with industrialized substrate for floriculture. These pots were arranged in $3 \mathrm{~m}$ long countertops with $1 \mathrm{~m}$ in width and $1 \mathrm{~m}$ from the ground inside the greenhouse.

The substrate used in the experiment was composed of carbonized rice rusck (30\%) and humus (70\%), where the water holding capacity of the pot (PC) was determined according to the methodology proposed by Kämpf et al. (2006), according to equation 1 :

$P C=P_{24 \text { hrs }}-P d r y$

where: $\mathrm{P}_{24 \text { hrs }}$ is the weight with the saturate substrate after 24 hours of rest and $P_{d r y}$ is the weight of the pot filled with the dry substrate.

Firstly, three pots were filled with the substrate. They were weighed and placed, at saturation, on aluminum trays containing water depth at constant level. The moistening of the substrate occurred through drills in the base of the pots. After saturation, they were weighed and placed to drain for 24 hours. During the draining, the pots had their surface covered to avoid evaporation. After drainage, the pots were weighed again and the mass of water was recorded. By using equation 1 and pot area, PC was obtained $(7.41 \mathrm{~mm})$.

$\mu=\underline{m}$

$\mathrm{V}$

Where: $\mu$ is the specific mass for the considered fluid; $m$ is the mass of the substance and $\mathrm{V}$ is the volume occupied by it.

The statistical design was the completely randomized, with four treatments and four replications. The treatments were at different levels of irrigation, replenishing the evaporated water depth based on pot capacity (PC), which were $40 \%, 60 \%, 80 \%$ and $100 \%$ of the PC.

Kalanchoe seedlings were formed in trays from $5 \mathrm{~cm}$ cuttings with five leaves. Transplanting of rooted cuttings to the pots was carried out 15 days after fixing them in the tray.

In the first seven days after transplanting (DAT) of seedlings, irrigation was performed with $100 \%$ of the PC. From the eighth DAT, management of irrigation was started. The irrigations were performed with fixed irrigation shifts, with a three-day interval, following proposal of Mello (2006).

The variables evaluated in all repetitions were: the vegetative canopy area (CA), number of leaves per plant (NFP), diameter of the canopy (DC), number of inflorescences per plant (NIP) and number of flowers per plant (NFLP). Number of leaves per plant were weekly evaluated by manual count of total leaves per plant, and vegetative canopy area as well, which was obtained by the product of leaf area times the number of leaves per plant. The leaf area was determined according to the methodology proposed by Moreira Filho et al. (2007).

At the end of the crop cycle, on 224 DAT, when the plants presented most inflorescences open, ID, NIP and NFLP were determined. Diameter of the inflorescence was obtained with the aid of the graduated ruler. The NIP and NFLP were determined by manual counting.

Data were submitted to analysis of variance. Later, when significant by $\mathrm{F}$ test, the effects of irrigation levels were submitted to regression analysis to adjust the equations. Linear and quadratic polynomial models were tested in regression analysis. The regression equation that best adjusted to the data was chosen based on the significance of the regression coefficients at $1 \%(\mathrm{P}<0.01)$ and $5 \%(\mathrm{p}<$ 0.05 ) of probability by F-test and at the largest value of coefficient of determination $\left(\mathrm{R}^{2}\right)$.

\section{RESULTS AND DISCUSSION}

Daily average water depth of irrigation applied during the crop cycle were $2.02 ; 1.64 ; 1.26$ and $0.89{\mathrm{~mm} . \text { day }^{-1} \text {, for }}^{-1}$ treatments 100, 80, 60 and $40 \%$ of PC, respectively.

Based on the results obtained from the analysis of variance shown in Table 1, significant effect was found at the level of probability of $5 \%$ of the depths applied to the number of leaves per plant, diameter of the canopy and number of inflorescence per plants. However, for the variable number of flowers per plant, the effect of irrigation levels was significant at the $1 \%$ level; no significant effect was found for the depths used in this work only for the canopy area.

As for the regression analysis of the canopy area in relation to irrigation depths, it was found that the second degree polynomial model presented the best adjustment, with coefficient of determination of 0.91 (Figure 1). The depth that obtained the highest values for the variable analyzed was that corresponding to $80 \%$ of the PC and a consumption of $367.36 \mathrm{~mm}$ for its post-transplant growth cycle. The maximum canopy area, calculated by the derivative of the interpolating equation of the second degree (Figure 1), was $1802.09 \mathrm{~cm}^{2}$, obtained with the application of a water depth of $76.68 \%$ of the PC.

Similar results were found by Parizi et al. (2010), in a work that quantified the effects of different irrigation depths on leaf growth and the number of leaves of Kalanchoe, cultivar "Gold Jewel". These authors observed the largest leaf area values in treatments with depths of 6,8 and $9 \mathrm{~mm}$, corresponding to the irrigation levels with 40, 50 and $60 \%$ of the PC. These researchers found that when plants were under extreme treatments of irrigation, that is, 12 and $100 \%$ of PC, they presented the lowest leaf area values, which 
was attributed to water deficit and water excess, respectively. Peiter et al, (2007) in a study that determined the water consumption of Kalanchoe blossfeldiana under different irrigation depths and the consequences of these strategies on production, concluded that the optimal level of irrigation for cultivar "Gold Jewel" was about 10 mm.day ${ }^{-1}$, which corresponds to an application of about $70 \%$ PC (10.11 mm.day ${ }^{-1}$ ). However, Girardi et al. (2014), when studying the effect of different levels of irrigation on the growth of Alstroemeria, observed that the largest leaf area values were found between treatments with 75 and $90 \%$ of PC, with the lowest values observed in irrigation treatments 20 and $40 \%$ of the PC.

Figure 2 presents the mathematical model adjusted for the average number of leaves per plant, in function of the applied irrigation depths. It can be seen that the average number of leaves per plant showed its growth peak in treatments that received water depths corresponding to $60 \%$ of the PC, corresponding to water consumption, for the growth cycle, of $282.24 \mathrm{~mm}$.

The maximum number of leaves per plant calculated by the derivative from the interpolating equation was 76.93 , obtained in the irrigation depth corresponding to $72.15 \%$ of PC (Figure 2). It can be seen that the smaller values of number of leaves per plant occurred when the cultivar was submitted to treatments with excess or deficit of irrigation, that is, both the stress and the water excess reduced the number of leaves per plant. The results corroborate Parizi et al. (2010) as they observed the largest values of number of leaves for plants in the treatments corresponding to 50 and $60 \%$ of PC. The authors emphasize that both excess and deficit of water significantly reduce the number of leaves per plant. Pereira et al. (2003), working with chrysanthemum under different levels of water replacement (40, 60, 80 and $100 \%$ replacement), noted that the number of leaves per plant was lower in the treatments with lower percentages of water replacement.

The average values of canopy diameter, according to the irrigation treatments, measured on 224 DAT, showed significant changes by the $\mathrm{F}$ test $(\mathrm{P}<0.05)$, by adjusting itself to a quadratic response, at regression analysis. The quadratic polynomial equation was set with an $\mathrm{R}^{2}$ of 0.9709 (Figure 3). From the adjusted equation, it was observed that the maximum diameter of the canopy $(0.24 \mathrm{~m})$ corresponded to the depth irrigation of $66.43 \%$ PC (average depth of $4.9 \mathrm{~mm}$.day ${ }^{-1}$ ). This fact evidences that both the

Table 1: Summary of the analysis of variance for canopy area (CA), diameter of the canopy (DC), number of flowers per plant (NFLP), number of inflorescence per plant (NIP) and number of leaves per plant (NLP), in Kalanchoe blossfeldiana Poelln. Crop

\begin{tabular}{lcccccc}
\hline \multirow{2}{*}{ Variation sources } & DF & \multicolumn{5}{c}{ Mean square } \\
\cline { 3 - 7 } & & CA $^{\mathrm{cm} 2}$ & $\mathbf{C D}^{\mathrm{m}}$ & $\mathbf{N F L P}$ & $\mathbf{N I P}$ & NLP \\
\hline Irrigation & 3 & $252,442.221 \mathrm{~ns}$ & $0.004^{*}$ & $31786.841^{* *}$ & $5.506^{*}$ & $768.580^{*}$ \\
RL & 1 & $248,409.902 \mathrm{~ns}$ & $0.000^{*}$ & $87362.170^{* *}$ & $0.401 \mathrm{~ns}$ & $106.790 \mathrm{~ns}$ \\
RQ & 1 & $444,559.696 \mathrm{~ns}$ & $0.011^{*}$ & $6710.341 \mathrm{~ns}$ & $2.506 \mathrm{~ns}$ & $2056.093^{* *}$ \\
Residue & 12 & $225,852.887$ & 0.001 & 3156.076 & 1.451 & 151.165 \\
\hline CV $(\%)$ & & 30.17 & 16.12 & 15.43 & 25.25 & 19.70 \\
\hline
\end{tabular}

DF: degrees of freedom; RL: first degree regression; RQ: second degree regression; CV: coefficient of variation; $* *$ significant at the level of $1 \%$ of probability $(\mathrm{P}<0.01)$; * significant at the level of $5 \%$ of probability $(\mathrm{P}<0.05)$; ns not-significant $(\mathrm{P}$ e" 0.05$)$.

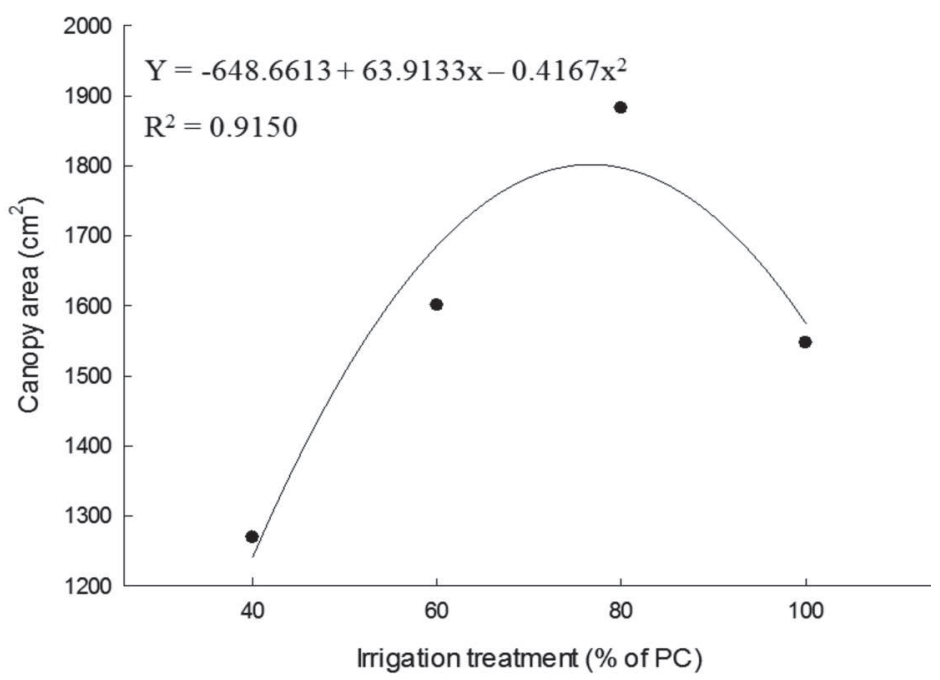

Figure 1: Canopy area according to the irrigation depths for kalanchoe Blossfeldiana Poelln. cultivar 'Simone' 
water excess and the deficit present a reduction in plant growth. Rêgo et al. (2004), working with water levels of 50, 75,100 and $125 \%$ of evaporation measured in " $A$ " class tank (ACT) in the chrysanthemum crop, found decreases in diameter rods, the stem length and weight of the stem, from the $100 \%$ level of ACT.

For the number of inflorescences per plant, according to the irrigation levels, a significant variation was found by the $\mathrm{F}$ test $(\mathrm{P}<0.05)$. None of the models evaluated in regression analysis adjusted to the data, showing that there was no response from the number of inflorescences per plant in function of the applied irrigation depths. It is noteworthy that the smaller number of inflorescences per plant (3.75) occurred when they were submitted to water depths of $40 \%$ of the PC, which corresponds to a water consumption of $199.36 \mathrm{~mm}$ during its growth cycle.
However, the highest number of inflorescences per plant (6.33) was observed in water depth of $60 \%$ of the PC, which is a depth that consumed during their cycle, $282.24 \mathrm{~mm}$. Similar results were reported by Soares et al. (2008) when studying the effect of different irrigation depths on the cultivar "Gold Jewel" of kalanchoe. They observed an average of 4.8 inflorescences per plant. Moreover, Peiter et al. (2007) found an average of 4.23 inflorescences per plant for the same cultivar.

It can be seen in Figure 4 that in the kalanchoe crop, both the excess and the water deficit resulted in a reduction in the number of inflorescences per plant. According to Bernardo (2002), water deficiency causes the closure of the stomata, reducing the intracellular concentration of $\mathrm{CO}_{2}$ and thus generating its decrease. Therefore, there is less production of photoassimilates and plant tissues. In

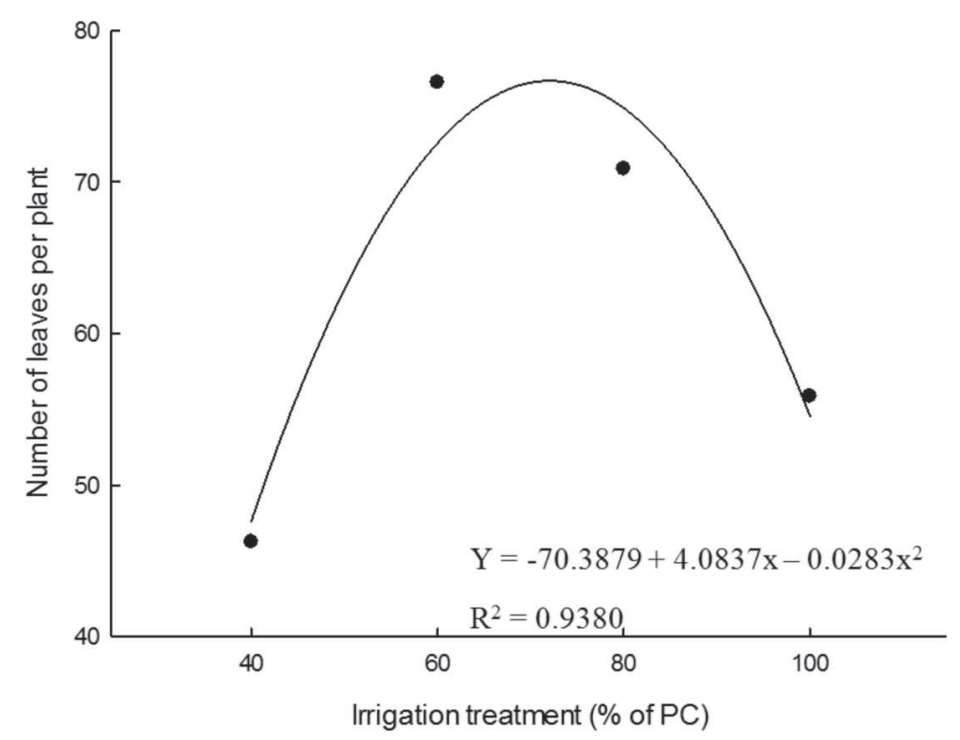

Figure 2: Number of leaf per plant according to the irrigations depths for kalanchoe Blossfeldiana Poelln. cultivar 'Simone'

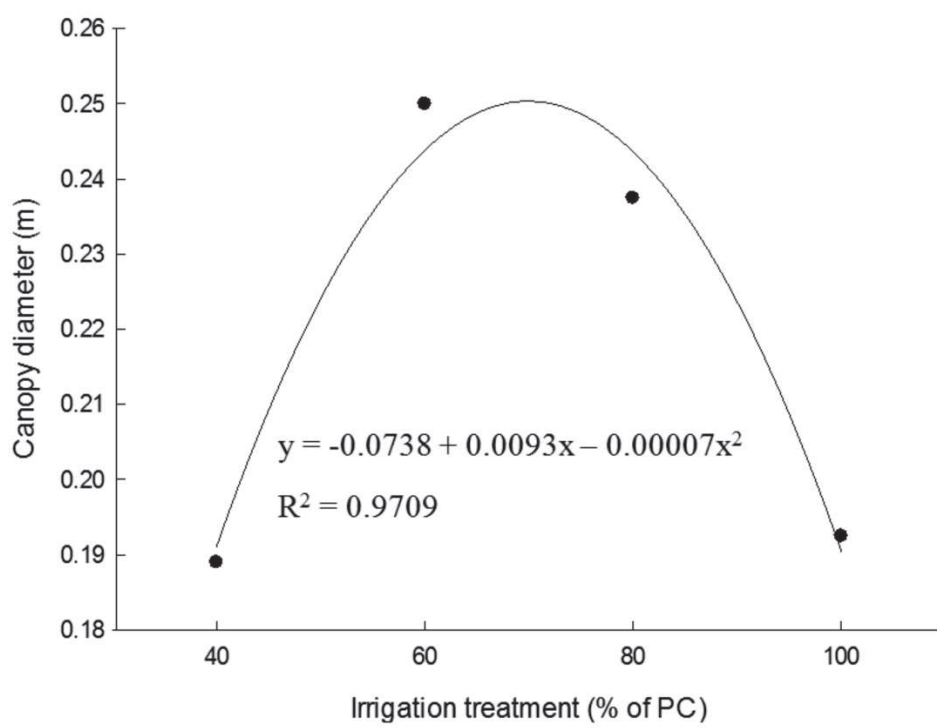

Figure 3: Canopy diameter according to the irrigation depths for kalanchoe Blossfeldiana Poelln. cultivar 'Simone' 
contrast, the water excess reduces pressure of oxygen (hypoxia) or its lack (anoxia), making the respiration of plants difficult, and therefore reducing the production of energy required for the synthesis and translocation of organic compounds and their active absorption. The lack of oxygen also decreases the photosynthesis, causing a smaller plant growth (Rêgo et al., 2004). These results agree partially with those found by Viana et al. (2004), who in a study whose objective was to study the effects of irrigation levels and to identify the best level of irrigation on the chrysanthemum crop, realized that the highest average diameters of inflorescences occurred in the depth with $100 \%$ evaporation of class A tank while smaller diameters were recorded in the treatments with 50 and $125 \%$ of the replacement of the tank evaporation. Similarly, Pereira et al. (2003), found the largest diameters of inflorescences for the depth of $100 \%$ of water consumed for chrysanthemum crop.

Figure 5 presents values of the number of flowers per plant in function of the irrigation water depth applied in different treatments. The model that best adjusted to this relationship was the linear one, with an $\mathrm{R}^{2}$ of 0.9161 . A tendency to linear reduction was found in the average number of flowers per plant, due to the increase of irrigation depths. It is found that the highest values of number of flowers per plant are the treatments with total depths of 282.24 and $199.36 \mathrm{~mm}$, corresponding to the replacement of 60 and $40 \%$ of the PC, respectively. In the other irrigation treatments, 100 and $80 \%$ of PC, lower values were found for the variable, which can be attributed to excess of water.

These results partially corroborate those found by Peiter et al. (2007) who determined the water consumption

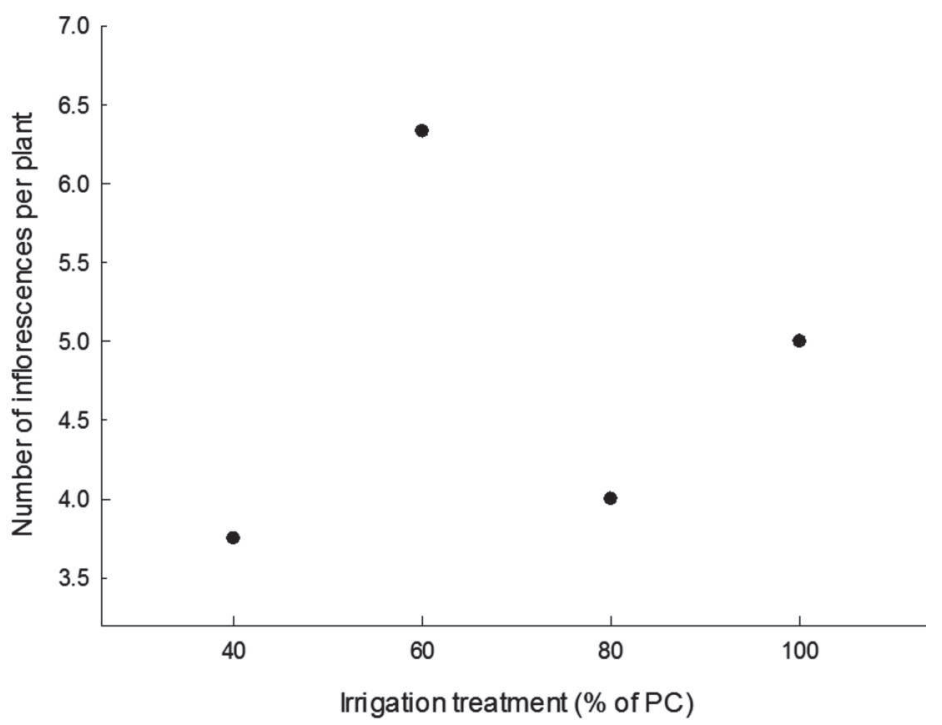

Figure 4: Number of inflorescences per plant according to irrigation depths for kalanchoe Blossfeldiana Poelln. cultivar 'Simone'

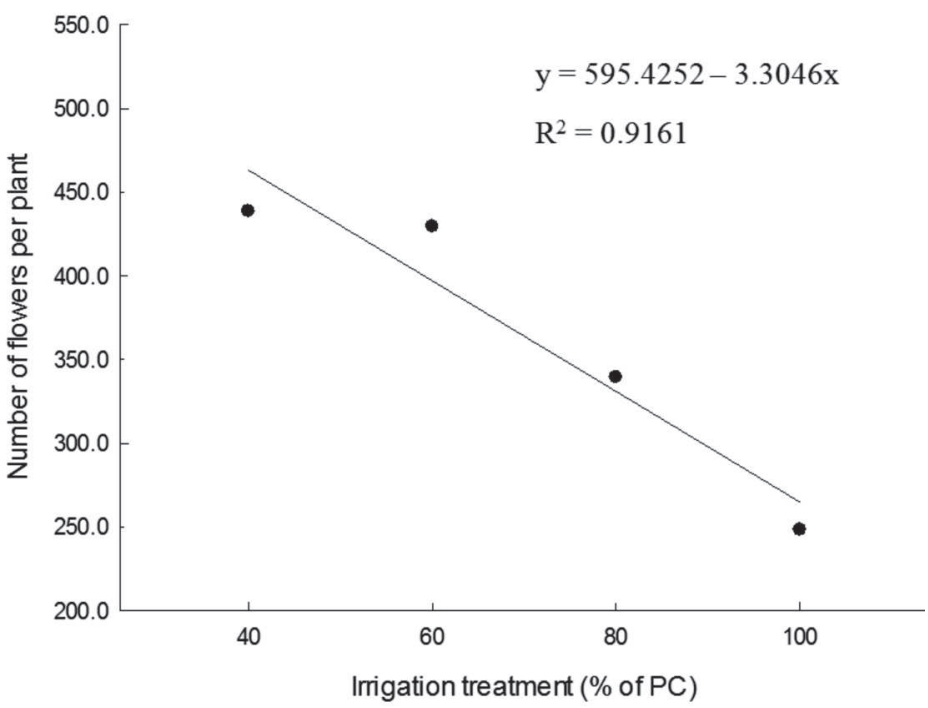

Figure 5: Number of flower per plant according to the irrigation depths for cultivar 'Simone' of kalanchoe Blossfeldiana Poelln. 
of Kalanchoe blossfeldiana under different irrigation depths, and the consequences of these strategies on production, concluding that the optimal level of irrigation for Kalanchoe blossfeldiana, "Gold Jewel" cultivar, grown in greenhouses, in the region of Santiago, state of Rio Grande do Sul, was approximately $117 \mathrm{~mm}$.

Marinho (2011), differently from the present study, did not obtain significant difference in the average mass of fruit of Tabasco cv. pepper when submitted to different levels of water deficit (40,60, 80 and 100\%) of crop evapotranspiration, started from its reproductive phase. Peiter et al. (2007) observed for the number of flowers per plant, a quadratic behavior directly proportional to the water depth increment.

\section{CONCLUSIONS}

Water conditions in which the subtract was submitted affected the growth of kalanchoe blossfeldiana Poelln, cultivar 'Simone'.

Irrigation depths between 40 and $70 \%$ of the pot capacity showed to be more adequate for the growth of cultivar in the region of study.

\section{REFERENCES}

Agronline (2008) Brasil tem 250 tipos de flores e setor movimenta mais de $\mathrm{R} \$ 2$ bilhões. Disponível em: <http:// www.agronline.com.br/agronoticias/noticia.php? $i d=3385 \geq$. Acessado em: 02 de dezembro de 2014.

Bellé S (2000) Irrigação de plantas ornamentais. In: Petry C (Ed.) Plantas ornamentais: aspectos para a produção. Passo Fundo, UPF. p.63-68.

Ben LHB (2015) Influência de lâminas de irrigação e densidades de plantas sobre o cultivo do milho safrinha. Dissertação de Mestrado. Universidade Federal de Santa Maria, Santa Maria. $104 \mathrm{p}$.

Bernardo S (2002) Manual de irrigação. 6 ${ }^{\mathrm{a}}$ ed. Viçosa, UFV. 656p.

Donatto V (2014) Mercado de Plantas Ornamentais. Disponíve em: <http://g1.globo.com/jornal-hoje/noticia/2014/02/mercado-de-plantas-ornamentais-e-flores-cresce-mais-de-8-nobrasil.html>. Acessado em: 02 de dezembro de 2014.

Epamig - Empresa de Pesquisa Agropecuária de Minas Gerais (2015) Floricultura. Disponível em: <http://www.epamig.br/index.php? option $=$ com_content $\&$ task=view $\& i d=276>$. Acessado em: 10 de fevereiro de 2016.

Girardi LB, Peiter MX, Robaina AD, Pereira AC, Kopp LM \& Mezzomo W (2014) Análise da área foliar de Alstroemeria em função da lâmina de irrigação. Tecnologia \& Ciência Agropecuária, 8:21-15.

Ibraflor - Instituto Brasileiro de Floricultura (2015) Números do setor. Disponível em: <http://www.ibraflor.com/ns_mer_interno. php>. Acessado em: 08 de fevereiro de 2016.

Kämpf AN (2000) Produção comercial de plantas ornamentais. Guaíba, Agropecuária. 254p.

Kämpf NA, Takane RJ \& Siqueira PTV de (2006) Floricultura: técnicas de preparo de substratos. Brasília, LK. 132p.
Kuinchtner A \& Buriol GA (2001) Clima do Estado do Rio Grande do Sul segundo a classificação climática de köppen e thornthwaite. Disciplinarum Scientia, 2:171-182.

Marinho LB (2011) Irrigação plena e com déficit em pimenta cv. Tabasco em ambiente protegido. Tese de Doutorado. Escola Superior de Agricultura "Luiz de Queiroz", Piracicaba. 102p.

Matiello JB, Santinato R, Garcia AWR, Almeida SR \& Fernandes DR (2005) Cultura do café no Brasil: novo manual de recomendações. $2^{\mathrm{a}}$ ed. Rio de Janeiro, MAPA/PROCAFÉ. 387p.

Mello RP (2006) Consumo de água do lírio asiático em vaso com diferentes substratos. Dissertação de Mestrado. Universidade Federal de Santa Maria, Santa Maria. 74p.

Moreira Filho EC, Silva DS, Pereira WE, Cabral Jr CR, Andrade MVM, Silva GE \& Viana BL (2007) Estimação da área foliar da flor de seda (Calotropis procera). Archivos de Zootecnia, 56:245248.

Parizi AR, Peiter MX, Robaina AD, Soares FC, Vivan GA \& Ramão CJ (2010) Níveis de irrigação na cultura do Kalanchoe cultivado em ambiente protegido. Ciência Rural, 40:864-861.

Paz VP da S, Teodoro REF \& Mendonça FC (2000) Recursos hídricos, agricultura irrigada e meio ambiente. Revista Brasileira de Engenharia Agrícola e Ambiental, 4:465-473.

Peiter MX, Parizi AR, Robaina AD \& Soares FC (2007) Consumo de água e produção da flor da fortuna CV. Gold Jewel sob diferentes lâminas de irrigação. Revista Irriga, 12:83-91.

Pereira JRD, Carvalho J de A, Paiva PD de O, Silva DJ da, Souza AMG de \& Souza KJ de (2003) Efeitos da época de suspensão da fertirrigação e níveis de reposição de água na cultura do crisântemo (dendranthema grandiflora). Ciência Agrotecnica, 27:658664.

Rêgo JL, Viana TVA, Azevedo BM, Bastos FGC \& Gondim RS (2004) Efeitos de níveis de irrigação sobre a cultura do crisântemo. Revista Ciência Agronômica, 35:302-308.

Sebrae - Serviço Brasileiro de Apoio às Micro e Pequenas Empresas (2010) Crescimento da Floricultura no Brasil. Disponível em: <http://www.sebrae.com.br/setor/floricultura/>. Acessado em: 08 de fevereiro de 2016.

Soares FC, Peiter MX, Robaina AD, Parizi R \& Ramão CJ (2008) Produtividade sazonal de kalanchoe cultivado em ambiente protegido e submetido a estratégias de irrigação. Revista Irriga, 13:492-506.

Viana TVA, Rego J de L, Azevedo BM de, Araujo WF \& Bastos FGC (2004) Efeitos de níveis de irrigação sobre o índice de área foliar, a matéria seca e o desenvolvimento da inflorescência da cultura do crisântemo. Revista Irriga, 9:248-255.

Vieira GHS, Mantovani EC, Sousa MBA de \& Bonomo R (2000) Influência de diferentes lâminas de irrigação nos parâmetros de crescimento do cafeeiro na região de Viçosa, MG. In: Simpósio de Pesquisa dos Cafés do Brasil, Poços de Calda. Anais, Minasplan. p.879-881. 